\title{
Resenha do Livro "As Cartas de Tsuji. A história de um pesquisador e seus alunos criando uma empresa de base tecnológica"
}

por Maria Helena de Araújo

livro "As Cartas de Tsuji. A história de um pesquisador e seus alunos criando uma empresa de base tecnológica" é um romance sobre a vida de um pesquisador acadêmico na área de ciência/engenharia que decide abrir uma empresa, mas não sabe como.

Esse livro foi escrito por três autores com diferentes formações, mas que se complementam fortemente dentro do enredo empreendedor: Rochel Montero Lago é professor pesquisador (Nível $1 \mathrm{C}$ CNPq) do Departamento de Química da UFMG, Euler J. Santos é economista com mestrado em Inovação Tecnológica na Holanda e diretorexecutivo da empresa Verti Ecotecnologias e Lilian Barros, professora da Universidade Federal de Itajuba, e administradora com mestrado em Empreendedorismo. É um livro que trata de educação empreendedora e tem como leitoralvo estudantes de graduação, pósgraduação

professores/pesquisadores das áreas de ciências naturais (química, física, biologia), todas as engenharias, farmácia, veterinárias e áreas como administração e economia.

No século do conhecimento e logo após perdermos Steve Jobs, empreendedorismo é um conceito que ganha força em todas as áreas. 0 significado deste conceito é a capacidade de transformar ideias em produtos. No entanto, para que isso aconteça é crucial a cultura empreendedora, já que ela é a força motriz que aciona todo este processo.

"As Cartas de Tsuji. A história de um pesquisador e seus alunos criando uma empresa de base tecnológica" joga luz sobre esse assunto de forma didática e atraente. O conteúdo é rico e trata dos principais aspectos do empreendedorismo

como propriedade intelectual, plano de negócios, perfil empreendedor e relações profissionais - tudo muito bem ilustrado e com exemplos clássicos da história mundial.

O romance começa com João (pesquisador) no leito de morte de seu mentor japonês, Tsuji que Ihe deixará uma caixa especial com cartas. Essas cartas serão abertas no decorrer do romance, e cada uma delas é uma "dica" para João no seu caminho empreendedor.

Tsuji Sensei, o mentor acadêmico empreendedor, passa parte da infância em um mosteiro Zen Budista e vai estudar engenharia elétrica em Tóquio. Ele participa diretamente da "guerra" entre o Japão e os EUA na indústria de micro-eletrônica e trabalhando no Vale do Silício conta várias histórias interessantes. Do outro lado, o pai de João, um português dono de uma padaria, é um empreendedor, mas, que, não entende a importância da ciência. Para explicar o valor da ciência nessa parte do romance aparece a Escola de Sagres (Portugal), a "NASA do século XIV", que agrupou sábios de todas as
Data de publicação na Web: 17 de Janeiro de 2012 Recebido em 08 de Janeiro de 2012 Aceito para publicação em 11 de Janeiro de 2012

áreas e de onde saíram grandes inovações para as navegações.

Ao longo do romance são colocados quadros técnicos que explicam temas como propriedade intelectual, estudos de mercado, perfil empreendedor, plano de negócio, importância de network, Vale do Silício, Rota 128, Escola de Sagres, entre outros.

$O$ romance a partir de um ponto segue por três caminhos diferentes: João decide abrir uma empresa, João não abre a empresa, mas decide licenciar a tecnologia para uma grande empresa e João decide não fazer nada com sua tecnologia e publica seus resultados em uma revista científica.

Vale a pena ler.

Boa Leitura!

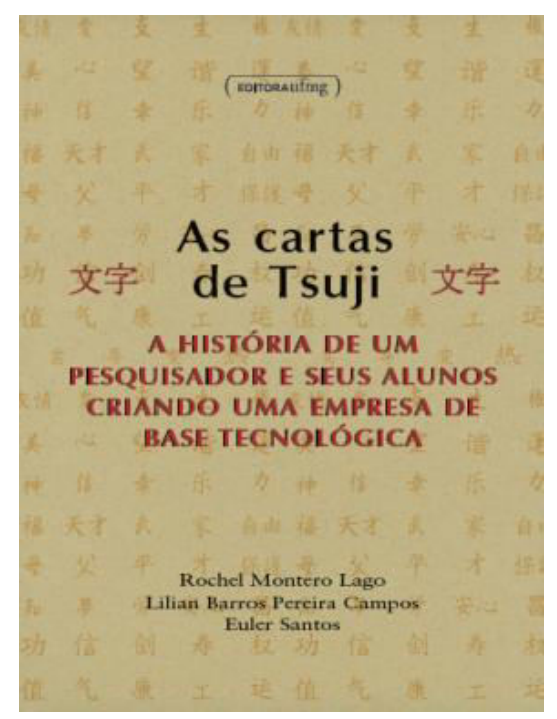

*Universidade Federal de Minas Gerais, Instituto de Ciências Exatas, Departamento de Química, Av. Antônio Carlos, 6627, CEP 31270-901, Belo Horizonte-MG, Brasil.

Mmharaujo1993@yahoo.com.br

DOI: $10.5935 / 1984-6835.20110057$ 